\title{
The Equatorial El Niño-Southern Oscillation Signatures Observed by FORMOSAT-3/COSMIC from July 2006 to January 2012
}

\author{
Yang-Yi Sun ${ }^{1}$, Jann-Yenq Liu ${ }^{1,2,3,{ }^{*}, \text { Ho-Fang Tsai }}{ }^{4}$, Chien-Hung Lin ${ }^{5}$, and Ying-Hwa Kuo ${ }^{6}$ \\ ${ }^{I}$ Graduate Institute of Space Science, National Central University, Jhongli, Taiwan \\ ${ }^{2}$ Center for Space and Remote Sensing Research, National Central University, Jhongli, Taiwan \\ ${ }^{3}$ National Space Organization, Hsinchu, Taiwan \\ ${ }^{4}$ GPS Science and Application Research Center, National Central University, Jhongli, Taiwan \\ ${ }^{5}$ Department of Earth Science, National Cheng Kung University, Tainan, Taiwan \\ ${ }^{6}$ University Corporation for Atmospheric Research, Boulder Colorado, USA
}

Received 24 December 2012, revised 3 February 2014, accepted 13 February 2014

\begin{abstract}
This paper uses the tropospheric pressure, temperature, and water vapor pressure observed by six micro-satellites of the FORMOSAT-3/COSMIC (F3/C) constellation to study El Niño-Southern Oscillation (ENSO) events from July 2006 to January 2012. The temperature and pressure profiles are used to derive the height, pressure, temperature, and potential temperature of the lapse rate tropopause. Following the calculation of the standard normalized Southern Oscillation Index (SOI) and the Niño 3.4 index, the corresponding indices of the four tropopause parameters are derived. Good agreements between the standard and F3/C-derived indices show that the derived indices are significant for monitoring ENSO signatures. With the uniform coverage, the global F3/C profiles are used to construct three-dimensional structures of temperature, pressure, and water vapor pressure to gain a better understanding of tropospheric structures and dynamics during the ENSO events.
\end{abstract}

Key words: FORMOSAT-3/COSMIC, ENSO, Tropospheric dynamics

Citation: Sun, Y. Y., J.Y. Liu, H.F.Tsai, C. H. Lin, and Y. H. Kuo, 2014: The Equatorial El Niño-Southern Oscillation signatures observed by FORMOSAT-3/ COSMIC from July 2006 to January 2012. Terr. Atmos. Ocean. Sci., 25, 545-558, doi: 10.3319/TAO.2014.02.13.01(A)

\section{INTRODUCTION}

El Niño is an important climate phenomenon with the distinct feature of El Niño being the warmer-than-normal sea surface temperature (SST) over the Equatorial Central and Eastern Pacific. This phenomenon has widespread impacts on natural conditions and environments, such as the reduction in fish and bird populations along the coast of Peru; the possible increase in the occurrence of droughts and flooding in certain regions; the formation and tracks of tropical cyclones, etc. (e.g., Rasmusson and Carpenter 1982; Philander 1989; Trenberth 1997; Wallace et al. 1998; Glantz 2000). The atmospheric component tied to El Niño is termed the "Southern Oscillation." Conventionally, this phenomenon is monitored by the normalized Southern Oscillation Index (SOI) (e.g., Trenberth 1984; Trenberth and Hoar 1996), which is defined as the monthly mean sea level pressure difference between Tahiti $\left(17.5^{\circ} \mathrm{S}, 149.6^{\circ} \mathrm{W}\right)$ and

\footnotetext{
* Corresponding author

E-mail:jyliu@jupiter.ss.ncu.edu.tw
}

Darwin, Australia, $\left(12.4^{\circ} \mathrm{S}, 130.9^{\circ} \mathrm{E}\right)$. This interaction between the atmosphere and ocean is referred to as the $\mathrm{El} \mathrm{Ni}-$ ño-Southern Oscillation (ENSO) (Trenberth 1997). El Niño then corresponds to the warm phase of ENSO. The cold phase of ENSO, referred to as La Niña, consists of a cooling in the Equatorial Central and Eastern Pacific. ENSO-neutral refers to the period when neither El Niño nor La Niña is present. The National Oceanic and Atmospheric Administration (NOAA) Climate Diagnostics Bulletin has proposed the SST index at Niño 3.4 region $\left(120^{\circ}-170^{\circ} \mathrm{W}, 5^{\circ} \mathrm{S}-5^{\circ} \mathrm{N}\right)$ as a proxy for these events. Currently the SOI and Niño 3.4 index are routinely published by various organizations (e.g., NOAA: http://www.cpc.noaa.gov/data/indices and the Australian Government Bureau of Meteorology: http://www. bom.gov.au/climate/enso). Based on the SOI and Niño 3.4 index published by NOAA, in the FORMOSAT-3/COSMIC (F3/C) observation period: 2006/2007 and 2009/2010 are ENSO warm events; 2007/2008, 2010/2011, and 2011/2012 are ENSO cold events; and 2008/2009 is an ENSO neutral 
period (neither El Niño nor La Niña); while 2009/2010 is the strongest ENSO warm event (Lee and McPhaden 2010; Su and Jiang 2013) in the past 12 years (since 1997/1998).

Gage and Reid (1987) used radiosonde data at Koror, Republic of Palau, $\left(7.33^{\circ} \mathrm{N}, 134.48^{\circ} \mathrm{E}\right)$ and Majuro, Marshall Is., $\left(7.08^{\circ} \mathrm{N}, 171.38^{\circ} \mathrm{E}\right)$ to study longitudinal variations in tropical tropopause properties in relation to tropical convection and ENSO events. They found that an index formed from the tropopause potential temperature differences between Koror and Majuro is closely related to the conventional SOI, confirming the systematic relationship of the longitudinal gradients of tropopause potential temperature to ENSO events at least for the period from 1970 - 1984. Randel et al. (2000) and Zhou et al. (2001) examined radiosonde data and also found that variations in the tropical tropopause parameters have a close relationship with ENSO in SOI and Niño 3.4 index. Zhou et al. (2001) examined the radiosonde observation of the cold point tropopause temperature near Niño 3.4 region and found that it is colder in El Niño events but warmer in La Niña events during 1976 - 1998. It has been known that variations in SSTs result in changes of the convection and circulation, which in turn affect tropopause quantities (Reid and Gage 1981, 1985; Gage and Reid 1987). Global circulation model (GCM) simulations also show that the tropopause height is sensitive to the temperature at the Earth's surface (Thuburn and Graig 1997). Processes in the troposphere and stratosphere have been thought to control the height of the tropopause (Birner 2010, and references therein). It seems that not only the tropospheric effects, but also activities in the lower stratosphere play important roles in the behaviors of the tropopause parameters. Therefore, the globally distributed $\mathrm{F} 3 / \mathrm{C}$ radio occultation $(\mathrm{RO})$ soundings provide us with a good opportunity to examine the relationship between the tropopause behavior and the ENSO-associated dynamics in the troposphere and the lower stratosphere.

In this study, the lapse rate tropopause is defined based on World Meteorological Organization (WMO) criterion and derived from the F3/C RO temperature profile. This corresponds to the lowest level at which the lapse rate decreases to $2^{\circ} \mathrm{C} \mathrm{km}^{-1}$ or less, provided also that the average lapse rate between this level and all higher levels within 2 $\mathrm{km}$ does not exceed $2^{\circ} \mathrm{C} \mathrm{km}^{-1}$ (WMO 1957). Schmidt et al. (2004) first demonstrated the global tropopause parameters using GPS RO data.

The co-located tropopause height, pressure, temperature, and potential temperature observed by the $\mathrm{F} 3 / \mathrm{C}$ are compared with the standard SOI and Niño 3.4 index. In Eq. (1) where pressure is $P$ and temperature is $T$, note that the potential temperature $\theta$ is defined as

$\theta=T\left(\frac{P_{0}}{P}\right)^{\frac{R}{C_{p}}}$

in which the reference pressure $\left(P_{0}\right)$ is chosen to be 1000 $\mathrm{mb}, R$ is the ideal gas constant, and $C_{p}$ is the specific heat capacity at constant pressure. Later, the three-dimensional structures of pressure, temperature, and water vapor pressure constructed by the $\mathrm{F} 3 / \mathrm{C}$ profiles are examined to gain a better understanding of the ENSO phenomenon from mid July 2006 to January 2012 .

\section{DATA}

The F3/C mission was successfully launched on 15 April 2006. Six identical micro-satellites, each carrying an advanced GPS receiver, measured the phase and the amplitude of the GPS radio signals (L1: $1575.42 \mathrm{MHz}$; L2: 1227.60 MHz). Using the precise orbit information of Low Earth Orbit (LEO) and GPS satellites, F3/C provides approximately 1000 - $2500 \mathrm{RO}$ soundings per day, distributed nearly uniformly around the globe. The F3/C RO bending angle and refractivity profiles contribute significantly to global atmospheric models and data assimilation systems (see the papers list in Anthes et al. 2008 and Anthes 2011). With the six micro-satellites, F3/C provides much higher temporal and spatial resolution measurements lower than 40 $\mathrm{km}$, which also allows us to study the atmospheric structure and dynamics in greater detail (Scherllin-Pirscher et al. 2012). The RO method for obtaining atmospheric soundings is described by Kursinski et al. $(1997,2000)$. The $T$, $P$, and water vapor pressure $\left(P_{w}\right)$ are estimated from the refractivity $N$,

$N=77.6 \frac{P}{T}+3.73 \times 10^{5} \frac{P_{w}}{T^{2}}$

(Smith and Weintraub 1953) using the one-dimensional variational data assimilation method (1D-Var) (http://cdaacwww.cosmic.ucar.edu/cdaac/doc/documents/1dvar.pdf). The background field used for the 1D-Var is the ERA-Interim reanalysis (http://cdaac-www.cosmic.ucar.edu/cdaac/). Kuo et al. (2004) showed that the RO observational errors are comparable to or smaller than 12-hour forecast errors of the NCEP (National Centers for Environmental Prediction) Aviation (AVN) model, except for the tropical lower troposphere. For the COSMIC Data Analysis and Archive Center (CDAAC) processing, the background error is assumed to be much larger than the GPS observational error. Therefore, such a small variation in the background error may not bring a noticeable change in the retrieval methodology (T. K. Wee 2008, personal communication). Commencing in mid July 2006, the data become more reliable so the CDAAC recommends that users should start using data from Day 194, 2006 (http://cdaac-www.cosmic.ucar.edu/cdaac/status.html). Accordingly, all monthly mean fields of July 2006 shown in this study are constructed using the F3/C observation from 13 - 31 July (Days 194 - 212) 2006. The F3/C data version used in this study is 2010.2640 . 
The tropospheric and stratospheric GPS RO measurements have been validated by numerous studies. Hajj et al. (2004) found that temperature profiles collected from CHAMP (Challenging Minisatellite Payload) and SAC-C (Satelite de Aplicaciones Cientificas-C) are consistent to $0.1 \mathrm{~K}$ in the mean and $0.86 \mathrm{~K}$ in standard deviation between 5 - $15 \mathrm{~km}$ altitude. Schreiner et al. (2007) reported that the root mean square difference in refractivity between collocated occultations with horizontal distance between tangent points $<10 \mathrm{~km}$ is less than $0.2 \%$ between $10-20 \mathrm{~km}$ altitude. Foelsche et al. (2011) established a good consistency in $\mathrm{RO}$ climatologies of refractivity and temperature from CHAMP, F3/C, and GRACE-A (Gravity Recovery and Climate Experiment). Narayana Rao et al. (2009) displayed good comparison in temperature of $\mathrm{F} 3 / \mathrm{C}$ and the Gadanki, India, $\left(13.48^{\circ} \mathrm{N}, 79.2^{\circ} \mathrm{E}\right)$ radiosonde between $10-27 \mathrm{~km}$ altitude. Ho et al. (2009) reported that the mean difference in the CHAMP and F3/C dry temperature between 500 and $10 \mathrm{hPa}$ is about $-0.034 \mathrm{~K}$, which demonstrates homogeneity of the GPS RO observation. He et al. (2009) found that the $\mathrm{F} 3 / \mathrm{C}$ temperature is very close to the temperature observations of Vaisala-RS92 (from several different countries) and Shanghai, China, radiosondes at around 12 - $25 \mathrm{~km}$ altitude and suggested that it is useful for assessing systematic errors in different radiosonde sensors. Kishore et al. (2009) validated the global F3/C GPS RO temperature with the NCEP reanalysis, the Japanese 25-year reanalysis (JRA-25), and the United Kingdom Met Office (MetO) data sets, and found good agreements among these data sets within 8 to $30 \mathrm{~km}$ altitude. In addition, Kishore et al. (2011) demonstrated that $\mathrm{F} 3 / \mathrm{C}$ derived water vapor information is reliable up to $8 \mathrm{~km}$. Xu and Luo (2008) reported that the mean absolute fractional pressure differences $\left[\left(\mathrm{P}_{\mathrm{F} 3 / \mathrm{C}}-\mathrm{P}_{\text {radiosonde }}\right) / \mathrm{P}_{\text {radiosonde }}\right]$ are generally less than $0.5 \%$ between $5-25 \mathrm{~km}$, and the mean absolute fractional pressure differences increase to be about $2 \%$ below $5 \mathrm{~km}$. F3/C RO profiles can also be retrieved above $40 \mathrm{~km}$ altitude, but the data could obviously be contaminated by ionospheric residuals above that altitude (e.g., Rocken et al. 1997; Syndergaard 2000). Ho et al. (2012) and Steiner et al. (2013) compared RO data from six different processing centers for the same time period (i.e., same ionospheric conditions) and found the largest differences at high altitudes due to different bending angle initialization approaches. Here we mainly examine the temperature and pressure observations between the $8-20 \mathrm{~km}$ altitude range and the water vapor pressure below $8 \mathrm{~km}$.

\section{TROPOPAUSE RESPONSE TO ENSO EVENTS}

To examine the tropopause response to the ENSO events we compare the co-located tropopause height, pressure, temperature, and potential temperature observed by the F3/C with the standard SOI and Niño 3.4 index provided by NOAA. Figure 1a illustrates an example of the monthly location of the F3/C RO soundings. It can be seen that the monthly F3/C observation has a uniform and dense spatial coverage. The F3/C soundings within the regions defined in Fig. 1a are used to derive the tropopause parameters, which are further applied to cross compare with the monthly standard SOI and Niño 3.4 index. We first isolate the F3/C tropopause height, temperature, pressure, and potential temperature over Tahiti and Darwin, follow the standard procedure of deriving the SOI (Trenberth and Hoar 1996), and compute the corresponding tropopause SOIs. Since both the tropopause height and tropopause potential temperature are inversely proportional to the sea level pressure in response to changes in tropical convections, the sign convention of the tropopause SOIs of the two quantities are set to be opposite to the tropopause pressure and temperature SOIs. Figure $1 \mathrm{~b}$ shows that variations of the tropopause height, pressure, temperature, and potential temperature SOIs agree well with that of the standard SOI from July 2006 to January 2012. The standard SOI and the tropopause SOIs have the highest correlation if a lag of zero or one month is taken into account as shown in Table 1, which is derived from Fig. 1b. Gage and Reid (1987) derived tropopause height and potential temperature SOIs using the radiosonde observations at Koror, (near Darwin longitude) and Majuro (near Tahiti longitude). They found that the tropopause potential temperature is more sensitive to the standard SOI than the tropopause height. However, the F3/C tropopause temperature/potential temperature SOI has the highest/lowest correlation with the standard SOI among the four tropopause parameters (Table 1). The discrepancy may be because Koror and Majuro are located near the equator, while the tropopause SOIs are derived over Darwin $\left(12.45^{\circ} \mathrm{S}\right)$ and Tahiti $\left(17.66^{\circ} \mathrm{S}\right)$, which lie in off-equator latitudes. The tropopause height and potential temperature have different latitudinal variations (Kishore et al. 2006).

Based on the definition of the standard Niño 3.4 index (Trenberth 1997), the tropopause Niño 3.4 indices are the normalized anomalies of the tropopause parameters obtained from the Niño 3.4 region. The anomalies are the departures from the mean annual cycle, which is derived from the mid July 2006 to January 2012 base period. To normalize the tropopause Niño 3.4 indices, the anomalies are further divided by the standard deviation of the anomalies during the entire period. Note that, in Fig. 1c, the sign convention of the tropopause Niño 3.4 indices of temperature and pressure has been reversed, because the tropopause temperature and pressure mainly decrease (increase) with increasing (decreasing) tropopause height. The increase/ decrease in the tropopause temperature in the La Niña/El Niño years is consistent with the statistical result reached by Zhou et al. (2001). Figure 1c illustrates that the tropopause Niño 3.4 indices and the standard Niño 3.4 index generally yield similar tendencies except for the tropopause potential temperature. The Niño 3.4 index reaches a small peak 


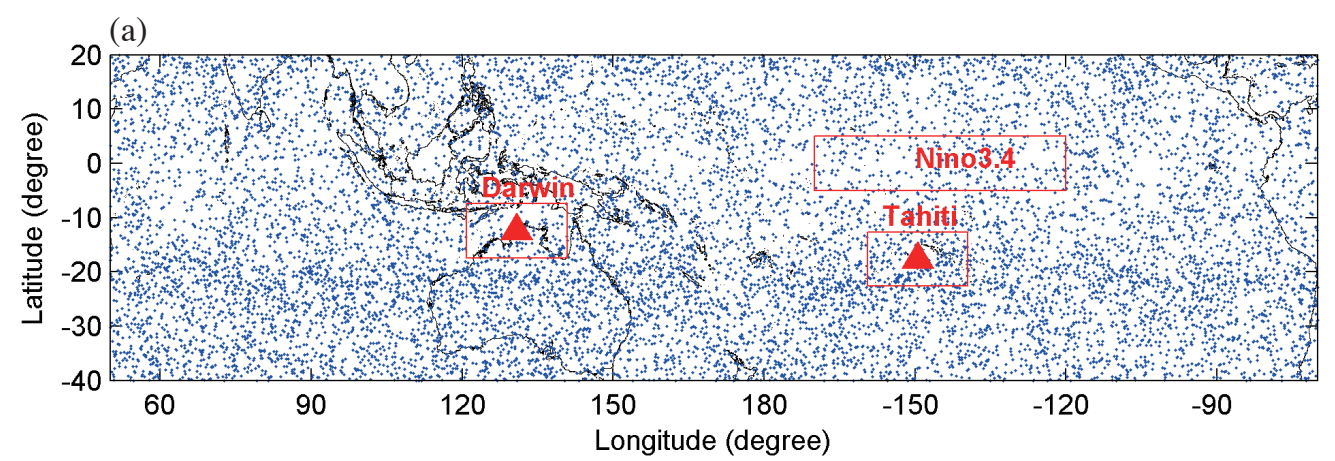

(b)

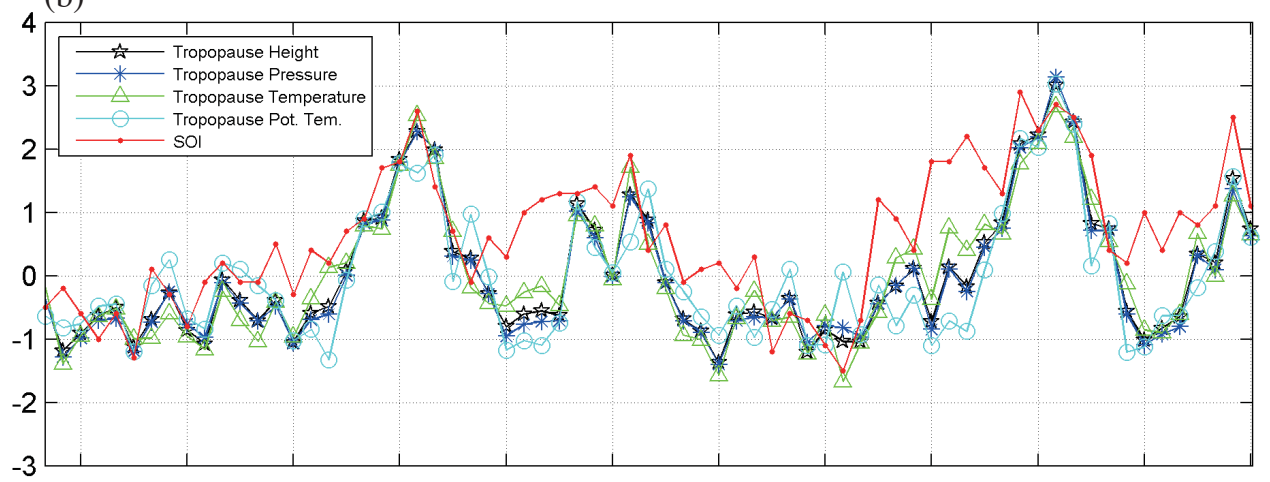

(c)

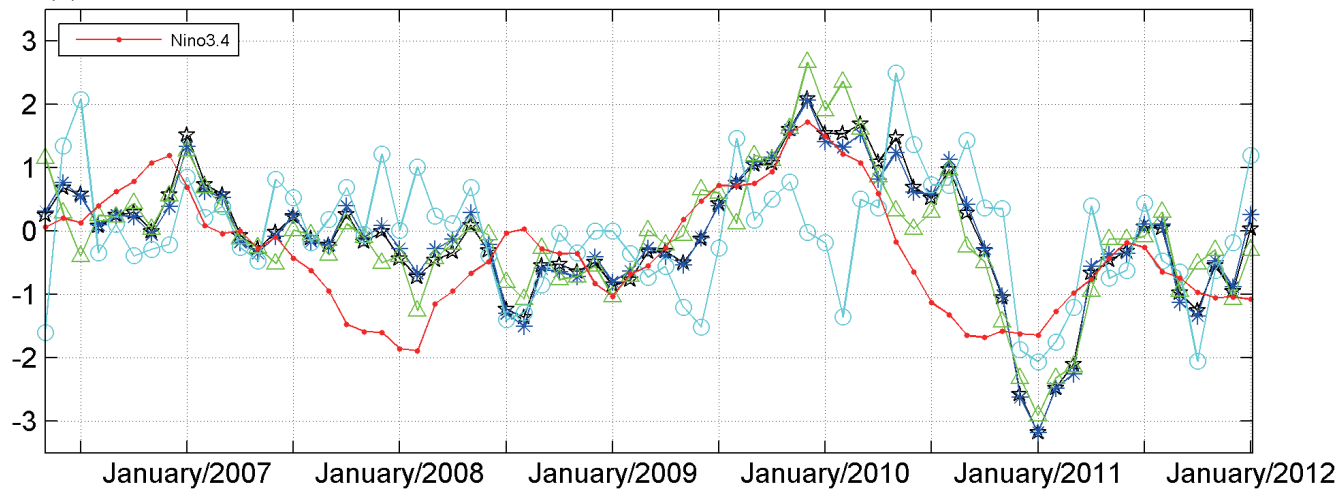

Fig. 1. Comparison of the standard Southern Oscillation Index (SOI) and Niño 3.4 index with the F3/C-derived tropopause ENSO indices, which are used to study the behavior of tropopause response to the El Niño-Southern Oscillation (ENSO) events. The figure shows (a) the regions used to derive the indices. The blue dots denote the locations F3/C atmospheric radio occultation sounding points in January 2007. The red rectangles indicate the regions of F3/C data used to compute the indices. (b) The standard SOI and (c) the Niño 3.4 index as well as the corresponding indices derived from the F3/C-observed tropopause height, pressure, temperature, and potential temperature during July 2006 to January 2012 . The tendency of the standard Niño 3.4 index seems to lead that of the tropopause Niño 3.4 indices by a couple of months. However, no obvious delay feature can be easily seen in the comparison of the SOIs.

Table 1. The correlation coefficients between the standard SOI and the tropopause SOIs, which were derived from Fig. 1b, have the highest value if a lag of zero or one month is taken into account.

\begin{tabular}{ccccc}
\hline Time lag (month) & Tropopause Height & Tropopause Pressure & Tropopause Temperature & Tropopause Potential Temp. \\
\hline 0 & 0.7619 & 0.7386 & 0.8163 & 0.5863 \\
1 & 0.7599 & 0.7439 & 0.8032 & 0.5998 \\
2 & 0.6478 & 0.6367 & 0.6735 & 0.5307 \\
3 & 0.5205 & 0.5052 & 0.5190 & 0.4506 \\
\hline
\end{tabular}


in December 2006, which leads that of the corresponding tropopause Niño 3.4 indices in January 2007 by one month. By contrast, the Niño 3.4 index and the tropopause Niño 3.4 indices yield close increasing tendencies throughout the entire year of 2009 , and no clear lagging features of the peak values can be found during the 2009/2010 ENSO warm period. In the following years, the Niño 3.4 index is significantly reduced after December 2009 goes negative in May 2010 and retains a minimum from September 2010 to January 2011. On the other hand, the zero-crossing going negative of the corresponding tropopause Niño 3.4 indices can be found from September to November 2010, and reach deep minima in January 2011. Table 2, derived from Fig. 1c, shows that correlations between the standard Niño 3.4 index and the tropopause height, pressure, and temperature Niño 3.4 indices reach maxima if the one or two months' lag is taken into account. By contrast, the tropopause potential temperature Niño 3.4 index yields rather low correlation with the standard Niño 3.4 index. Since $\theta \approx T / P$ the combined uncertainty of both $T$ and $P$ may cause significant errors and in turn result in the low correlation.

Tables 1 and 2 illustrate that the correlations between the standard SOI and the tropopause SOIs are generally higher than the correlations between the standard Niño 3.4 index and the tropopause Niño 3.4 indices. The different correlations may be because both the standard SOI and tropopause SOIs are derived by the atmospheric quantities, while the Niño 3.4 and the tropopause Niño 3.4 indices are computed from the oceanic and atmospheric observations, respectively. Furthermore, the tropopause Niño 3.4 indices lagging the Niño 3.4 index by one or two months (Fig. 1c and Table 2) mainly agrees with the finding of Scherllin-Pirscher et al. (2012) in which the atmospheric eddy (deviations from the zonal-mean) component takes about one month to respond to the ENSO forcing at the tropopause altitude. This may be because that the direct convection activated by the SST anomaly (SSTA) response in the atmosphere is displaced about one to two months later (e.g., Sobel et al. 2002; Kumar and Hoerling 2003; Su et al. 2005; Chou and Lo 2007). The short lag results from the adjustment of tropospheric convections and SST anomalies (Sobel et al. 2002).

Figure 2 reveals monthly global structures of the tropopause height in six July 2006 - 2011 maps and six January 2007 - 2012 maps. The tropopause heights in the six July periods are similar, which reach the highest altitude $(16.5 \mathrm{~km})$ at $30^{\circ} \mathrm{N}$ between $20^{\circ}$ and $120^{\circ} \mathrm{E}$ near the Tibetan Plateau area $\left(70^{\circ}-105^{\circ} \mathrm{E}\right)$. This is consistent with the pattern of the upper tropospheric (200 - $500 \mathrm{mb})$ temperature in the boreal summer (Webster et al. 1998). A strong heat source around and over the Tibetan Plateau produces intense temperature gradients in both the zonal and meridional directions, which play an important role in the evolution of the Asian summer monsoon (Webster et al. 1998), and the monsoonassociated upward convection may result in the increase in tropopause height around and over the Tibetan Plateau area. On the other hand, in the January period, tropopause heights generally exceed $16.5 \mathrm{~km}$ altitude in the tropical region except for those over the Eastern Pacific region $\left( \pm 20^{\circ} \mathrm{N}\right.$, $110^{\circ}-150^{\circ} \mathrm{W}$ ) during the ENSO cold and neutral events. By contrast, the entire equatorial tropopause height exceeds $16.5 \mathrm{~km}$ in January 2007 and 2010 for the two ENSO warm events. In comparison with the ENSO cold and neutral conditions, the tropopause height contours of $>17 \mathrm{~km}$ altitude over the Western Pacific region become broadened and expand across $180^{\circ} \mathrm{E}$, while those over the South and Central America regions are simultaneously enhanced during the two ENSO warm events. The seasonal and spatial characteristics of the global tropopause height structure observed by F3/C (Fig. 2) are generally consistent with the earlier RO observations of CHAMP and SAC-C in the northern summer (June - August) and winter (December - February) seasons (Schmidt et al. 2004; Kishore et al. 2006).

Figure 3 illustrates temporal and longitudinal variations in the F3/C-derived monthly tropopause height from July 2006 to January 2012. Figure 3a displays the tropopause height averaged within $\pm 20^{\circ} \mathrm{N}$. The tropopause height is pronounced in the entire longitudinal sector during the December - May period, except over the Equatorial Eastern Pacific (about $100^{\circ}-170^{\circ} \mathrm{W}$ ), and during the ENSO cold and the neutral conditions. Figure $3 \mathrm{~b}$ illustrates changes in the tropopause height in the ENSO events with respect to the ENSO neutral period of July 2008 to June 2009 (white area). It can be seen that two pronounced height enhancements appear around $110^{\circ}-170^{\circ} \mathrm{W}$ from November 2006 to March 2007, and November 2009 to March 2010 (the two ENSO warm events), and the latter $(>1 \mathrm{~km})$ is higher than the former (about $0.5 \mathrm{~km}$ ). Note that for the most prominent ENSO warm event in 2009/2010, a remarkable positive deviation appears as early as July to August 2009 over the Western Pacific region $\left(120^{\circ} \mathrm{E}-170^{\circ} \mathrm{W}\right)$.

\section{TEMPORAL AND SPATIAL TROPOSPHERE STRUCTURES RESPONSE TO ENSO EVENTS}

Scherllin-Pirscher et al. (2012) examined the F3/C temperature observation during 2006 - 2010 and found that the interannual temperature anomalies in the equatorial region show a natural decomposition into zonal-mean and eddy (deviations from the zonal-mean) components, both of which are related to the ENSO. The monthly mean anomalies shown by Scherllin-Pirscher et al. (2012) are obtained from subtracting the mean annual cycle at each grid point, and the mean annual cycle is calculated from January 2007 to December 2010. In this study, to simultaneously demonstrate all of the longitudinal, altitudinal, and temporal variations in the ENSO associated temperature, pressure, and water vapor pressure anomalies, the monthly mean deviations are departures from the annual cycle at each altitude grid point. The annual cycle 
Table 2. The correlation coefficients between the standard Niño 3.4 index and the tropopause Niño 3.4 indices, which were derived from Fig. 1c, have the highest value if one or two months are taken into account except for the tropopause potential temperature.

\begin{tabular}{ccccc}
\hline Time lag (month) & Tropopause Height & Tropopause Pressure & Tropopause Temperature & Tropopause Potential Temp. \\
\hline 0 & 0.6262 & 0.5733 & 0.7149 & -0.0041 \\
1 & 0.7066 & 0.6432 & 0.7710 & 0.0618 \\
2 & 0.7418 & 0.6750 & 0.7567 & 0.1701 \\
3 & 0.7272 & 0.6639 & 0.7037 & 0.2434 \\
\hline
\end{tabular}

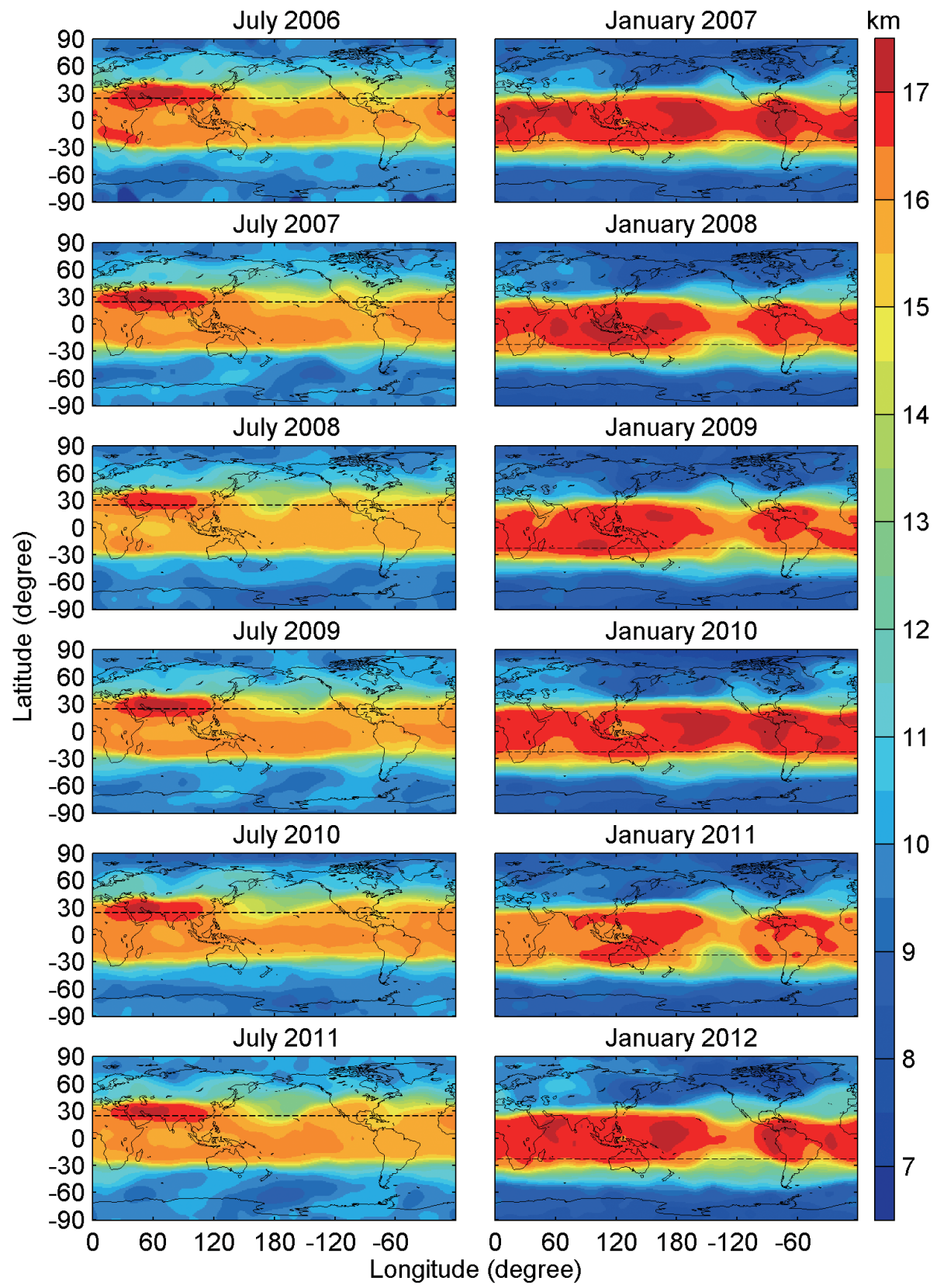

Fig. 2. Monthly maps of global structures of the F3/C-derived tropopause height for July 2006 - 2011 (left) and January 2007 - 2012 (right). These reveal that the tropopause height reaches the highest altitude $(16.5 \mathrm{~km})$ near $30^{\circ} \mathrm{N}$ between $20^{\circ}-120^{\circ} \mathrm{E}$, including the Tibetan Plateau region, in July 2006 - 2011. The tropopause height exceeds $16.5 \mathrm{~km}$ for the entire equatorial region in January 2007 and 2010 for the two ENSO warm events. The dashed lines denote the Tropic of Cancer or Capricorn, respectively. 
(a)

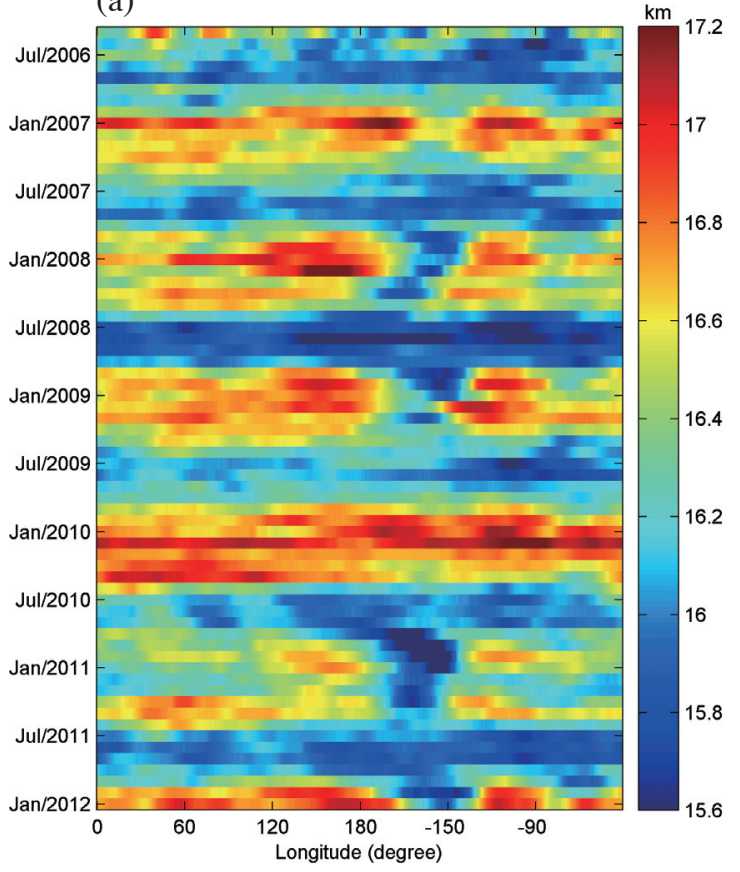

(b)

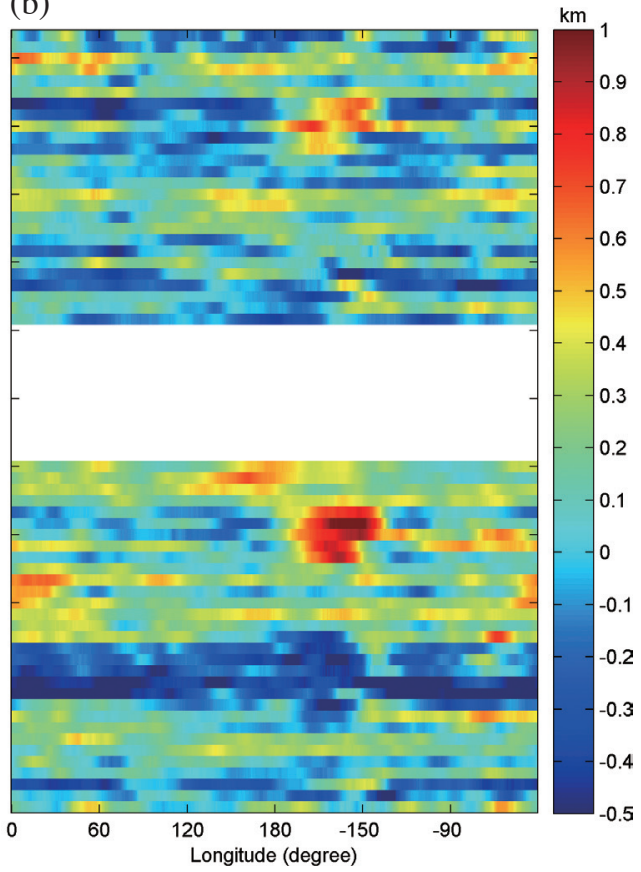

Fig. 3. F3/C-derived temporal and longitudinal tropopause height variations from July 2006 to January 2012. Shown in (a) is the tropopause height within $\pm 20^{\circ} \mathrm{N}$. Shown in (b) is the difference in tropopause height between the ENSO warm/cold events and the ENSO neutral condition [July 2008 to June 2009 (white area)]. A positive deviation, which accompanies the major ENSO warm signature in the Eastern Pacific region $\left(110^{\circ}-170^{\circ} \mathrm{W}\right)$ near January 2010, appears as early as July to August 2009 over the Western Pacific region $\left(120 \mathrm{E}^{\circ}-170^{\circ} \mathrm{W}\right)$.

consists of the monthly averages of all associated observations at each altitude grid point within a latitude belt of $\pm 5^{\circ} \mathrm{N}$ only during the ENSO neutral period from July 2008 to June 2009. Figures 4 to 6 illustrate the altitude/longitude slices for deviations of the pressure, temperature, and water vapor pressure in the equatorial atmosphere (within $\pm 5^{\circ} \mathrm{N}$ ) during six July 2006 - 2011 and six January 2007 - 2012 periods. These monthly deviations were smoothed using a $9 \times 9$ moving average window and the horizontal and vertical resolutions are $5^{\circ}$ and $0.1 \mathrm{~km}$, respectively. Note that the retrieval of the RO temperature and pressure is difficult below $8 \mathrm{~km}$ due to the interference from water vapor. Therefore, although we show the temperature, pressure, and water vapor pressure in the entire range of $0-20 \mathrm{~km}$, we mainly examine the temperature and pressure observations between the $8-20 \mathrm{~km}$ altitude range, and limit the discussion of the water vapor pressure to below $8 \mathrm{~km}$.

It can be seen that the ENSO warm signatures of the pressure, temperature, and water vapor pressure in January 2010 appear as early as July 2009. This is consistent with the occurrence of the remarkable positive tropopause height deviation in July to August 2009 (Fig. 3b). Compared to the ENSO cold and neutral conditions the positive temperature deviation between the $8-15 \mathrm{~km}$ altitude range over the Western Pacific region anomalously increases and expands eastward across $180^{\circ} \mathrm{E}$ in January 2007 and 2010 (Fig. 4), which corresponds to the occurrence of the expanded positive water vapor deviation in the equatorial lower tropo- sphere around $180^{\circ} \mathrm{E}$ (Fig. 5). The temperature deviations become negative around the tropopause and reach minima in the lower stratosphere. The character of the tropospherestratosphere temperature dipole is mainly consistent with the dominant pattern (EOF-1) of the global three-dimensional reanalysis temperature (Trenberth and Smith 2006, 2009). Lau et al. (1998) suggested that the dipole signature is fundamentally due to the rising of the tropopause associated with hydrostatic expansion and vertical ascent in regions of enhanced deep convection. Moreover, the equatorial temperature anomalies associated with the quasi-biennial oscillation $(\mathrm{QBO})$ in the lower stratosphere are of the order of $\pm 4 \mathrm{~K}$ (Baldwin et al. 2001). This means that the QBO can also dominate the temperature variation in the lower stratosphere. Furthermore, Taguchi (2010) and Huang et al. (2012) reported the evidence of the connection between the QBO and tropical Pacific SSTA and ENSO, and suggested the exact mechanism needs further studies.

It has been known that the SST and the sea level pressure affect the Walker circulation along the equator (Webster 1983; Webster and Chang 1988). In Fig. 6, we adopt the Walker circulation flow patterns from Webster and Chang (1988) and overlap them on the altitude/longitude pressure deviations in January of the two ENSO warm events, the three ENSO cold events, and the neutral condition. In general, the deviation of pressure agrees with the Walker circulation flow pattern of Webster and Chang (1988). The warm SST together with low sea level pressure causes upward 

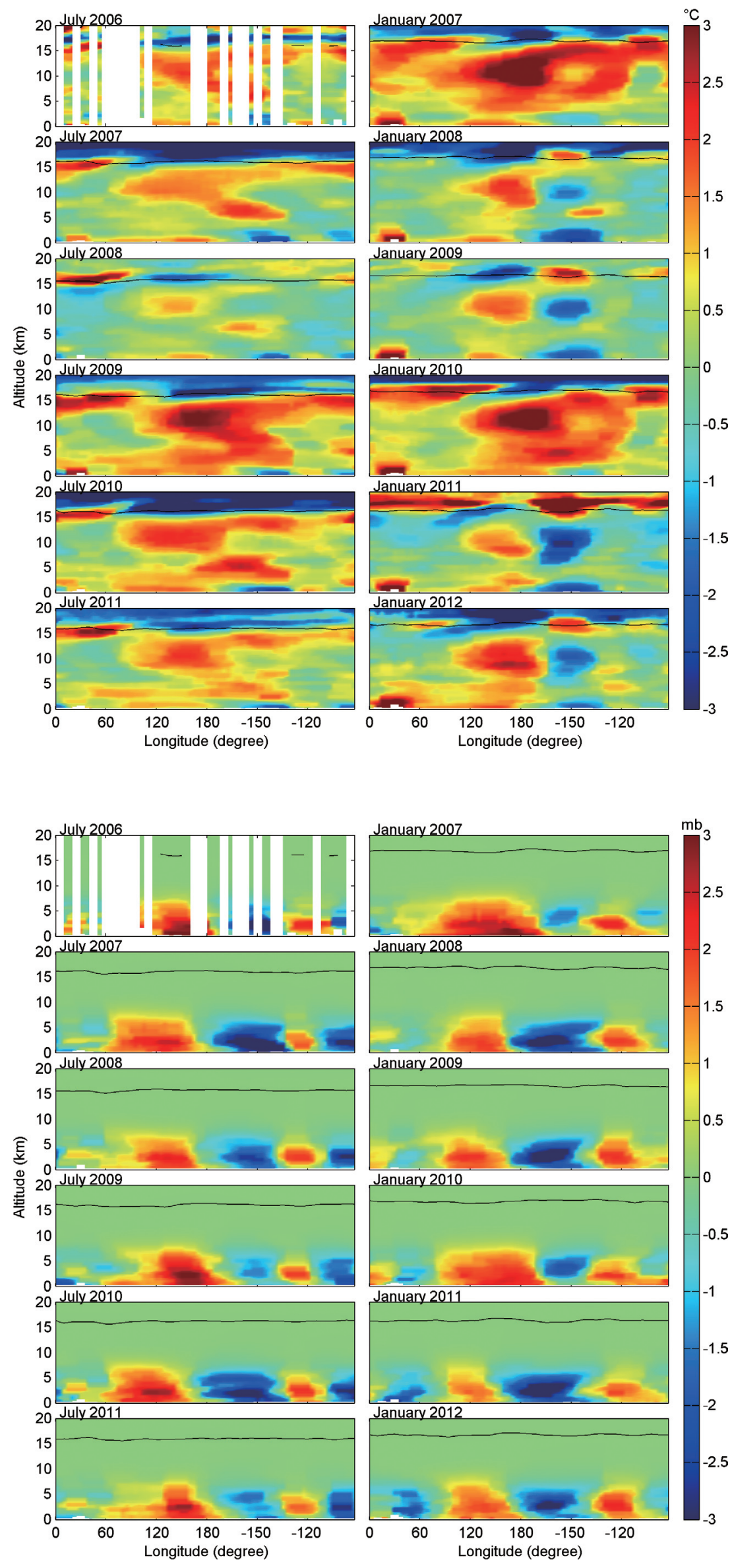

Fig. 4. Illustration of the structure of ENSO-associated temperature anomalies captured by F3/C. Altitude/ longitude slices of the monthly temperature deviation are shown within $\pm 5^{\circ} \mathrm{N}$ for July 2006 - 2011 (left) and January 2007 - 2012 (right). The black lines denote the tropopause height. The positive division is most pronounced in the upper troposphere (about $8-15 \mathrm{~km}$ ) over the tropical Pacific region during the two ENSO events. The existence of data gaps in July 2006 is because the $\mathrm{F} 3 / \mathrm{C}$ can only process a few hundred RO atmospheric sounding profiles per day during the first few months after launch (Fong et al. 2008).
Fig. 5. Illustration of the structure of ENSO-associated water vapor pressure anomalies captured by F3/C. Altitude/longitude slices of the monthly deviations are shown of water vapor pressure within $\pm 5^{\circ} \mathrm{N}$ for July 2006 - 2011 (left) and January 2007 - 2012 (right). The high water vapor pressure region expands .5 and crosses the International Date Line $\left(180^{\circ} \mathrm{E}\right)$ from the Western Pacific region during the two ENSO warm events. 

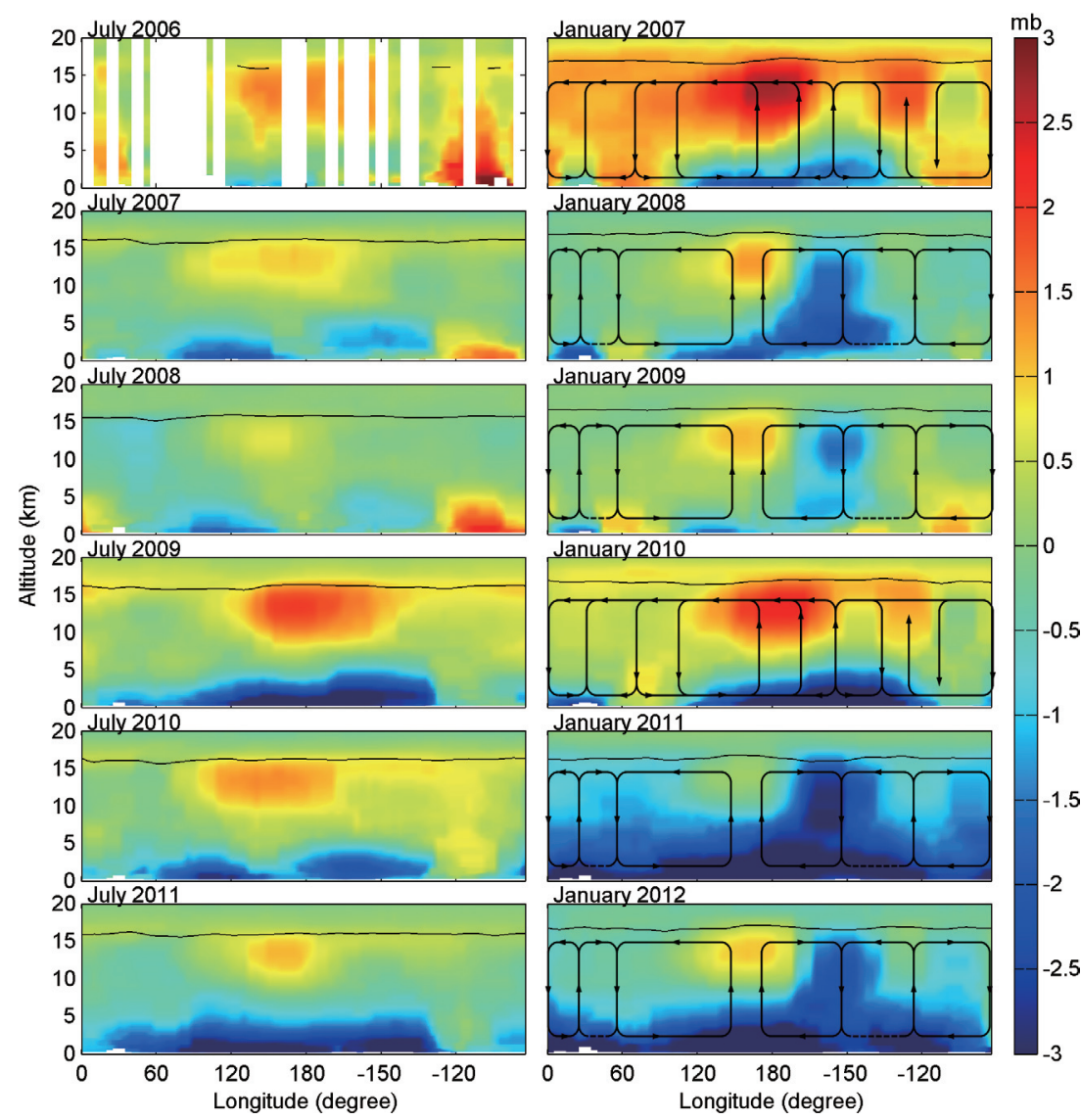

Fig. 6. Illustration of the structure of ENSO-associated pressure anomalies captured by F3/C. Altitude/ longitude slices of the monthly pressure deviations are shown within $\pm 5^{\circ} \mathrm{N}$ for July 2006 - 2011 (left) and January 2007 - 2012 (right). The deviation of pressure in January generally agrees with the Walker circulation flow pattern (adopted from Webster and Chang 1988) during both the ENSO and neutral conditions. convections consecutively affecting the Walker circulations during the January 2007 and January 2010 ENSO warm events, which are very different from those during the ENSO cold and neutral events. The warmer tropospheric temperature results in more evaporation and stronger convection during the two ENSO warm events, which allows a large amount of water vapor to develop in the equatorial troposphere (Fig. 5), and further increases the rainfall and thunderstorm activity over the Central and Eastern Pacific (Ropelewski and Halpert 1987, 1989).

To examine the time evolution of the ENSO signatures in detail, we construct time series of the deviation of pressure, temperature, and water vapor pressure in the equatorial regions of the Western and Eastern Pacific from July 2006 to January 2012. In Figs. 7 and 8, the time series are averaged from the deviations (derived from Figs. 4 - 6) within $120^{\circ}-180^{\circ} \mathrm{E}$ and $120^{\circ}-180^{\circ} \mathrm{W}$, and no smoothing procedure was applied for constructing Figs. 7 and 8. Figure 7a shows that the pressure deviation over the Equatorial Western Pacific region $\left( \pm 5^{\circ} \mathrm{N}, 120^{\circ}-180^{\circ} \mathrm{E}\right)$ undergoes semiannual oscillations (SAO) at about $5-20 \mathrm{~km}$ and reaches maxima near July and January. The intensity of the later maximum (near January) is much greater than the earlier one (near July) during the ENSO warm and neutral conditions. By contrast, the maximum in January is weaker than that in July during the ENSO cold conditions. Moreover, the two intense peaks merge into a massive one from January - August of the 2009/2010 ENSO warm event; however the merged peak is weaker in the 2006/2007 ENSO warm event. These features are generally consistent with those of the tropopause-derived Niño 3.4 index shown in Fig. 1c.

The similar SAO signature also appears in the temperature within $8-15 \mathrm{~km}$ (Fig. 7b), but it is hardly noticeable below $8 \mathrm{~km}$, which may be one of the reasons why the SAO cannot be found in water vapor pressure (Fig. 7c). Alternatively, the water vapor pressure near the ocean surface yields a negative deviation during the three ENSO cold events, and the most intense negative deviation occurs from September 2010 to February 2011. By contrast, the positive deviation becomes very pronounced during the two ENSO warm events. For cross comparisons, the deviation of pressure, temperature, and water vapor pressure over the equatorial region of the Eastern Pacific $\left(120^{\circ}-180^{\circ} \mathrm{W}\right)$ are constructed. Again, similar SAOs in deviations of pressure (Fig. 8a) and temperature (Fig. 8 b) can be observed during the two ENSO warm events. However, the later maxima (near January) become minima in the ENSO cold and neutral conditions. Figure $8 \mathrm{c}$ illustrates that the water vapor pressure anomaly below $6 \mathrm{~km}$ remains mainly negative except in January 2007, July 2009, and February - April 2010. 
(a)

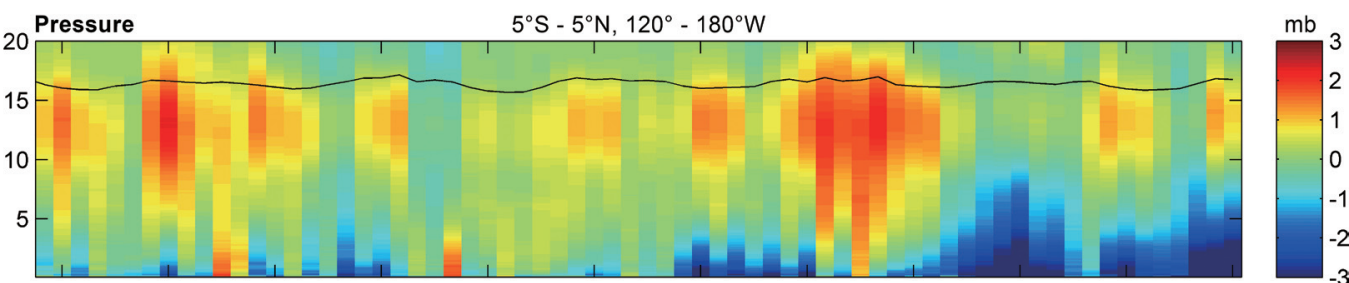

(b) 20 Temperature

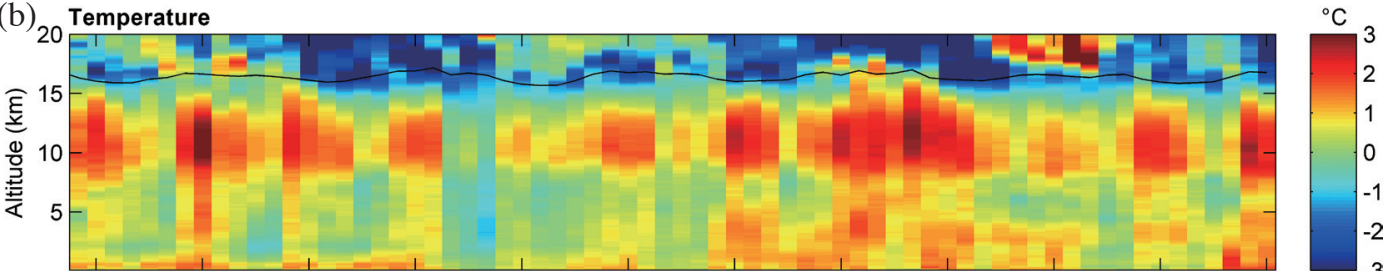

(c) 20 Water vapor pressure

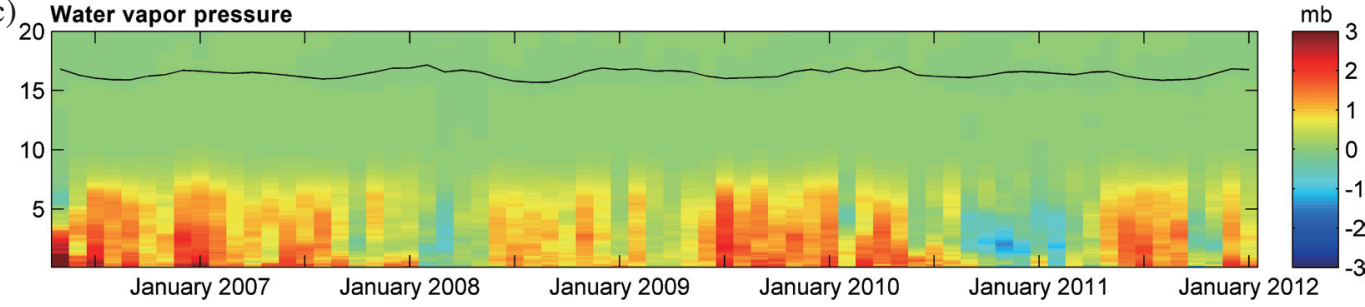

Fig. 7. Time series of the deviation of altitude profiles $\left(0-20 \mathrm{~km}\right.$ ) of (a) pressure, (b) temperature, and (c) water vapor pressure between $\pm 5^{\circ} \mathrm{N}$, and Western Pacific region $\left(120^{\circ}-180^{\circ} \mathrm{E}\right)$ from July 2006 to January 2012 . The mixture of the ENSO warm and semi-annual oscillations (SAO) signatures can be found in the divisions of pressure and temperature in the upper troposphere.

(a)

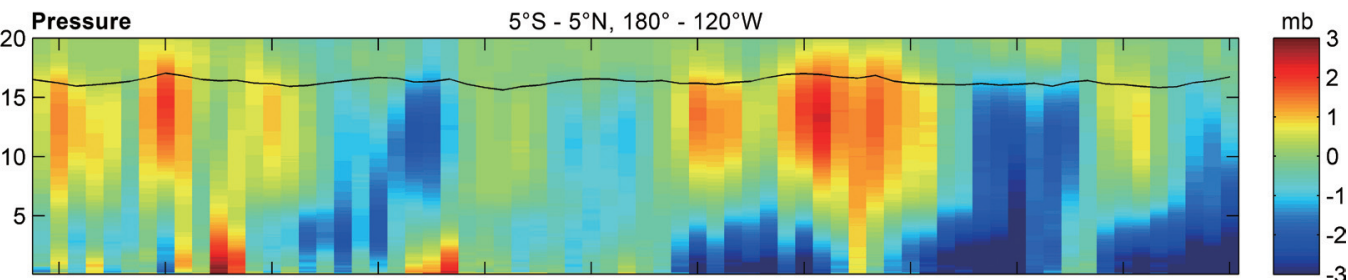

(b) 20 Temperature

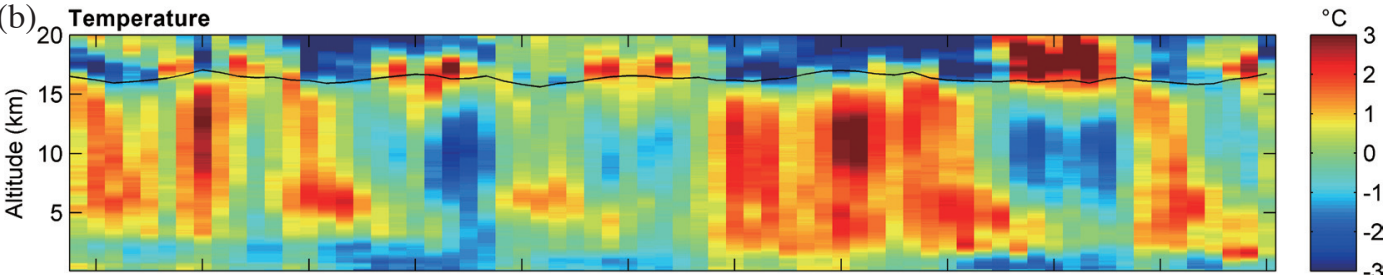

(c) 20 Water vapor pressure

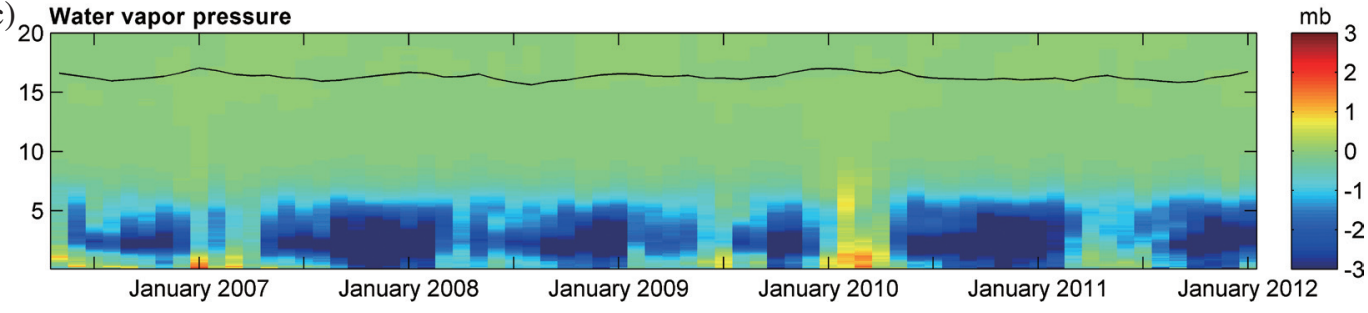

Fig. 8. Time series of the deviation of altitude profiles $(0-20 \mathrm{~km})$ of (a) pressure, (b) temperature, and (c) water vapor pressure between $\pm 5^{\circ} \mathrm{N}$, and Eastern Pacific region $\left(120^{\circ}-180^{\circ} \mathrm{W}\right)$ from July 2006 to January 2012 . Compared to Fig. 7 , no obvious semi-annual oscillations (SAO) signatures can be found in the Eastern Pacific as opposed to the Western Pacific region. 


\section{DISCUSSION AND CONCLUSION}

Liang et al. (2011) demonstrated that the interannual variability modes of the ENSO and the quasi-biannual oscillation both impact the equatorial tropopause temperature. However, the interannual variability of the tropopause height in the equatorial region seems not importantly affected by the QBO (Fig. 3 and Schmidt et al. 2008). The tropopause height may be more desirable than the tropopause temperature to examine the ENSO effects in the upper troposphere and lower stratosphere regions. Yulaeva and Wallace (1994) and Fernández et al. (2004) used the microwave sounding unit (MSU) temperature and showed that warm anomalies appear in temperatures of the lower and middle troposphere near the International Date Line several months before the strongest anomaly develops in the Eastern Pacific. This pattern is mainly consistent with the tropopause height variation during the 2009/2010 ENSO warm event (Fig. 3b). It reveals that the rising of the tropopause in the Western and Central Pacific is mainly associated with the thermal expansion and the tropospheric convection associated with ENSO (e.g., Lau et al. 1998; Gettelman et al. 2001).

The SAO of wind and temperature in the tropical troposphere have been thought to be associated with the movement of the Intertropical Convergence Zone crossing the Equator and modulations of the mean meridional circulation, while the precise mechanism for SAO has still not been fully understood (Read and Castrejón-Pita 2012). Van Loon and Jenne (1969) found a marked longitudinal asymmetry of the SAO to be considerably stronger in the Eastern than in the Western Hemisphere. It agrees with the results in Figs. 7 and 8 illustrating that the SAO is obvious in the Equatorial Western Pacific region (Fig. 7), but becomes obscure in the Equatorial Eastern Pacific region especially during the ENSO neutral and cold periods (Fig. 8). The most pronounced SAO, which exists over the Eastern Pacific during 2006/2007 and 2009/2010, seems to be associated with the enhancement and eastern movement of warm sea surface water and upward convections (Fig. 6) during the ENSO warm condition. Moreover, the maximum of the SAO near July 2009 of the ENSO warm event is much stronger than those of the ENSO cold and neutral events. This reveals that the maximum near July may be a possible precursor to an ENSO warm event.

In conclusion, the agreement between the standard SOI/Niño 3.4 index and the corresponding tropopause indices indicates that the F3/C-derived tropopause parameters are significant for monitoring the ENSO events. The global/ uniform distributed tropopause height observations and the altitude/longitude slices of the deviations of temperature, pressure, and water vapor pressure in the equatorial region demonstrate that the location of the East-West Walker circulation cell is essential to the ENSO-associated anomalies created in the troposphere. The F3/C tropospheric pressure profiles provide the $3-\mathrm{D}$ structure and dynamics of the
Walker circulation as well as temperature and water vapor pressure response to the ENSO events. The time evolution of deviations in pressure and temperature reveals that the ENSO warm events greatly affect the formation of the SAO at both the Western and Equatorial Eastern Pacific regions.

Acknowledgments This work was supported by National Space Organization (NSPO) grant, NSPO-S-099010(G). Yang-Yi Sun sincerely thanks Karen Fay O'Loughlin for her valuable assistance with the paper. Jann-Yenq Liu is grateful to the Advanced Study Program and the High Altitude Observatory of the National Center for Atmospheric Research. The authors wish to thank Drs. Hanli Liu and Loren Chang for useful discussions and suggestions.

\section{REFERENCES}

Anthes, R. A., 2011: Exploring Earth's atmosphere with radio occultation: Contributions to weather, climate and space weather. Atmos. Meas. Tech., 4, 1077-1103, doi: 10.5194/amt-4-1077-2011. [Link]

Anthes, R. A., P. A. Bernhardt, Y. Chen, L. Cucurull, K. F. Dymond, D. Ector, S. B. Healy, S. P. Ho, D. C. Hunt, Y. H. Kuo, H. Liu, K. Manning, C. McCormick, T. K. Meehan, W. J. Randel, C. Rocken, W. S. Schreiner, S. V. Sokolovskiy, S. Syndergaard, D. C. Thompson, K. E. Trenberth, T. K. Wee, N. L. Yen, and Z. Zeng, 2008: The COSMIC/FORMOSAT-3 mission: Early results. Bull.Amer. Meteorol.Soc., 89, 313-333, doi: 10.1175/ BAMS-89-3-313. [Link]

Baldwin, M. P., L. J. Gray, T. J. Dunkerton, K. Hamilton, P. H. Haynes, W. J. Randel, J. R. Holton, M. J. Alexander, I. Hirota, T. Horinouchi, D. B. A. Jones, J. S. Kinnersley, C. Marquardt, K. Sato, and M. Takahashi, 2001: The quasi-biennial oscillation. Rev. Geophys., 39, 179-229, doi: 10.1029/1999RG000073. [Link]

Birner, T., 2010: Residual circulation and tropopause structure. J. Atmos. Sci., 67, 2582-2600, doi: 10.1175/ 2010JAS3287.1. [Link]

Chou, C. and M. H. Lo, 2007: Asymmetric responses of tropical precipitation during ENSO. J. Climate, 20, 3411-3433, doi: 10.1175/JCLI4197.1. [Link]

Fernández, N. C., R. R. García, R. G. Herrera, D. G. Puyol, L. G. Presa, E. H. Martín, and P. R. Rodríguez, 2004: Analysis of the ENSO signal in tropospheric and stratospheric temperatures observed by MSU, 1979-2000. J. Climate, 17, 3934-3946, doi: 10.1175/1520-0442(2004)017<3934:AOTESI>2.0.CO;2. [Link]

Foelsche, U., B. Scherllin-Pirscher, F. Ladstädter, A. K. Steiner, and G. Kirchengast, 2011: Refractivity and temperature climate records from multiple radio occultation satellites consistent within $0.05 \%$. Atmos. Meas. Tech., 4, 2007-2018, doi: 10.5194/amt-4-2007-2011. [Link] 
Fong, C. J., S. K. Yang, C. H. Chu, C. Y. Huang, J. J. Yeh, C. T. Lin, T. C. Kuo, T. Y. Liu, N. Yen, S. S. Chen, Y. H. Kuo, Y. A. Liou, S. Chi, 2008: FORMOSAT-3/COSMIC constellation spacecraft system performance: After one year in orbit. IEEE Trans. Geosci. Remote Sensing, 46, 3380-3394, doi: 10.1109/ TGRS.2008.2005203. [Link]

Gage, K. S. and G. C. Reid, 1987: Longitudinal variations in tropical tropopause properties in relation to tropical convection and El Niño-Southern Oscillation events. J. Geophys. Res., 92, 14197-14203, doi: 10.1029/ JC092iC13p14197. [Link]

Gettelman, A., W. J. Randel, S. Massie, F. Wu, W. G. Read, and J. M. Russell III, 2001: El Niño as a natural experiment for studying the tropical tropopause region. J. Climate, 14, 3375-3392, doi: 10.1175/1520-0442(2001)014<3375:ENOAAN>2.0.CO;2. [Link]

Glantz, M. H., 2000: Currents of Change: Impacts of El Niño and La Niña on Climate and Society, $2^{\text {nd }}$ edition, Cambridge University Press, Cambridge, UK, 268 pp.

Hajj, G. A., C. O. Ao, B. A. Iijima, D. Kuang, E. R. Kursinski, A. J. Mannucci, T. K. Meehan, L. J. Romans, M. de la Torre Juarez, and T. P. Yunck, 2004: CHAMP and SAC-C atmospheric occultation results and intercomparisons. J. Geophys. Res., 109, D06109, doi: 10.1029/2003JD003909. [Link]

He, W., S. Ho, H. Chen, X. Zhou, D. Hunt, and Y. H. Kuo, 2009: Assessment of radiosonde temperature measurements in the upper troposphere and lower stratosphere using COSMIC radio occultation data. Geophys. Res. Lett., 36, L17807, doi: 10.1029/2009GL038712. [Link]

Ho, S. P., M. Goldberg, Y. H. Kuo, C. Z. Zou, and W. Schreiner, 2009: Calibration of temperature in the lower stratosphere from microwave measurements using COSMIC radio occultation data: Preliminary results. Terr. Atmos. Ocean. Sci., 20, 87-100, doi: 10.3319/ TAO.2007.12.06.01(F3C). [Link]

Ho, S., D. Hunt, A. K. Steiner, A. J. Mannucci, G. Kirchengast, H. Gleisner, S. Heise, A. von Engeln, C. Marquardt, S. Sokolovskiy, W. Schreiner, B. ScherllinPirscher, C. Ao, J. Wickert, S. Syndergaard, K. B. Lauritsen, S. Leroy, E. R. Kursinski, Y. H. Kuo, U. Foelsche, T. Schmidt, and M. Gorbunov, 2012: Reproducibility of GPS radio occultation data for climate monitoring: Profile-to-profile inter-comparison of CHAMP climate records 2002 to 2008 from six data centers. J. Geophys. Res., 117, D18111, doi: 10.1029/2012JD017665. [Link]

Huang, B., Z. Z. Hu, J. L. Kinter III, Z. Wu, and A. Kumar, 2012: Connection of stratospheric QBO with global atmospheric general circulation and tropical SST. Part I: Methodology and composite life cycle. Climate Dyn., 38, 1-23, doi: 10.1007/s00382-011-1250-7. [Link]

Kishore, P., S. P. Namboothiri, K. Igarashi, J. H. Jiang, C.
O. Ao, and L. J. Romans, 2006: Climatological characteristics of the tropopause parameters derived from GPS/CHAMP and GPS/SAC-C measurements. J. Geophys. Res., 111, D20110, doi: 10.1029/2005JD006827. [Link]

Kishore, P., S. P. Namboothiri, J. H. Jiang, V. Sivakumar, and K. Igarashi, 2009: Global temperature estimates in the troposphere and stratosphere: A validation study of COSMIC/FORMOSAT-3 measurements. Atmos. Chem. Phys., 9, 897-908, doi: 10.5194/acp-9-8972009. [Link]

Kishore, P., M. V. Ratnam, S. P. Namboothiri, I. Velicogna, G. Basha, J. H. Jiang, K. Igarashi, S. V. B. Rao, and V. Sivakumar, 2011: Global $\left(50^{\circ} \mathrm{S}-50^{\circ} \mathrm{N}\right)$ distribution of water vapor observed by COSMIC GPS RO: Comparison with GPS radiosonde, NCEP, ERA-Interim, and JRA-25 reanalysis data sets. J. Atmos. Sol.-Terr. Phys., 73, 1849-1860, doi: 10.1016/j.jastp.2011.04.017. [Link]

Kumar, A. and M. P. Hoerling, 2003: The nature and causes for the delayed atmospheric response to El Niño. $J$. Climate, 16, 1391-1403, doi: 10.1175/1520-044216.9.1391. [Link]

Kuo, Y. H., T. K. Wee, S. Sokolovskiy, C. Rocken, W. Schreiner, D. Hunt, and R. A. Anthes, 2004: Inversion and error estimation of GPS radio occultation data. $J$. Meteorol. Soc. Jpn., 82, 507-531.

Kursinski, E. R., G. A. Hajj, J. T. Schofield, R. P. Linfield, and K. R. Hardy, 1997: Observing Earth's atmosphere with radio occultation measurements using the Global Positioning System. J. Geophys. Res., 102, 2342923465, doi: 10.1029/97JD01569. [Link]

Kursinski, E. R., G. A. Hajj, S. S. Leroy, and B. Herman, 2000: The GPS radio occultation technique. Terr. Atmos. Ocean. Sci., 11, 53-114.

Lau, K. M., C. H. Ho, and I. S. Kang, 1998: Anomalous atmospheric hydrologic processes associated with ENSO: Mechanisms of hydrologic cycle-radiation interaction. J. Climate, 11, 800-815, doi: 10.1175/15200442(1998)011<0800:AAHPAW>2.0.CO;2. [Link]

Lee, T. and M. J. McPhaden, 2010: Increasing intensity of El Niño in the central-equatorial Pacific. Geophys. Res. Lett., 37, L14603, doi: 10.1029/2010GL044007. [Link]

Liang, C. K., A. Eldering, A. Gettelman, B. Tian, S. Wong, E. J. Fetzer, and K. N. Liou, 2011: Record of tropical interannual variability of temperature and water vapor from a combined AIRS-MLS data set. J. Geophys. Res., 116, D06103, doi: 10.1029/2010JD014841. [Link]

Narayana Rao, D., M. V. Ratnam, S. Mehta, D. Nath, S. G. Basha, V. V. M. J. Rao, B. V. K. Murthy, T. Tsuda, and K. Nakamura, 2009: Validation of the COSMIC radio occultation data over gadanki $\left(13.48^{\circ} \mathrm{N}, 79.2^{\circ} \mathrm{E}\right)$ : A tropical region. Terr. Atmos. Ocean. Sci., 20, 59-70, 
doi: 10.3319/TAO.2008.01.23.01(F3C). [Link]

Philander, S. G., 1989: El Niño, La Niña, and the Southern Oscillation, International Geophysics, Vol. 46, Academic Press, San Diego, CA, 293 pp.

Randel, W. J., F. Wu, and D. J. Gaffen, 2000: Interannual variability of the tropical tropopause derived from radiosonde data and NCEP reanalyses. J. Geophys. Res., 105, 15509-15523, doi: 10.1029/2000JD900155. [Link]

Rasmusson, E. M. and T. H. Carpenter, 1982: Variations in tropical sea surface temperature and surface wind fields associated with the Southern Oscillation/El Niño. Mon. Weather Rev., 110, 354-384, doi: 10.1175/1520-0493(1982)110<0354:VITSST>2.0.CO;2. [Link]

Read, P. L. and A. A. Castrejón-Pita, 2012: Phase synchronization between stratospheric and tropospheric quasi-biennial and semi-annual oscillations. Q. J.R. Meteorol. Soc., 138, 1338-1349, doi: 10.1002/qj.1872. [Link]

Reid, G. C. and K. S. Gage, 1981: On the annual variation in height of the tropical tropopause. J. Atmos. Sci., 38, 1928-1938, doi: 10.1175/1520-0469(1981)038<1928: OTAVIH>2.0.CO;2. [Link]

Reid, G. C. and K. S. Gage, 1985: Interannual variations in the height of the tropical tropopause. J. Geophys. Res., 90, 5629-5635, doi: 10.1029/JD090iD03p05629. [Link]

Rocken, C., R. Anthes, M. Exner, D. Hunt, S. Sokolovskiy, R. Ware, M. Gorbunov, W. Schreiner, D. Feng, B. Herman, Y. H. Kuo, and X. Zou, 1997: Analysis and validation of GPS/MET data in the neutral atmosphere. J. Geophys. Res., 102, 29849-29866, doi: 10.1029/97JD02400. [Link]

Ropelewski, C. F. and M. S. Halpert, 1987: Global and regional scale precipitation patterns associated with the El Niño/Southern Oscillation. Mon. Weather Rev., 115, 1606-1626, doi: 10.1175/1520-0493(1987)115<1606:GARSPP>2.0.CO;2. [Link]

Ropelewski,C.F. and M.S. Halpert, 1989: Precipitation patterns associated with the high index phase of the Southern Oscillation. J. Climate, 2, 268-284, doi: 10.1175/15200442(1989)002<0268:PPAWTH>2.0.CO;2. [Link]

Scherllin-Pirscher, B., C. Deser, S. P. Ho, C. Chou, W. Randel, and Y. H. Kuo, 2012: The vertical and spatial structure of ENSO in the upper troposphere and lower stratosphere from GPS radio occultation measurements. Geophys. Res. Lett., 39, L20801, doi: 10.1029/2012GL053071. [Link]

Schmidt, T., J. Wickert, G. Beyerle, and C. Reigber, 2004: Tropical tropopause parameters derived from GPS radio occultation measurements with CHAMP. J. Geophys. Res., 109, D13105, doi: 10.1029/2004JD004566. [Link]

Schmidt, T., J. Wickert, G. Beyerle, and S. Heise, 2008: Global tropopause height trends estimated from GPS radio occultation data. Geophys. Res. Lett., 35, L11806, doi: 10.1029/2008GL034012. [Link]

Schreiner, W., C. Rocken, S. Sokolovskiy, S. Syndergaard, and D. Hunt, 2007: Estimates of the precision of GPS radio occultations from the COSMIC/FORMOSAT-3 mission. Geophys. Res. Lett., 34, L04808, doi: 10.1029/2006GL027557. [Link]

Smith, E. K. and S. Weintraub, 1953: The constants in the equation for atmospheric refractive index at radio frequencies. J. Res. Bur. Stand., 50, 39-41.

Sobel, A. H., I. M. Held, and C. S. Bretherton, 2002: The ENSO signal in tropical tropospheric temperature. $J$. Climate, 15, 2702-2706, doi: 10.1175/1520-0442(2002)015<2702:TESITT>2.0.CO;2. [Link]

Steiner, A. K., D. Hunt, S. P. Ho, G. Kirchengast, A. J. Mannucci, B. Scherllin-Pirscher, H. Gleisner, A. von Engeln, T. Schmidt, C. Ao, S. S. Leroy, E. R. Kursinski, U. Foelsche, M. Gorbunov, S. Heise, Y. H. Kuo, K. B. Lauritsen, C. Marquardt, C. Rocken, W. Schreiner, S. Sokolovskiy, S. Syndergaard, and J. Wickert, 2013: Quantification of structural uncertainty in climate data records from GPS radio occultation. Atmos. Chem. Phys., 13, 1469-1484, doi: 10.5194/acp-13-1469-2013. [Link]

$\mathrm{Su}, \mathrm{H}$. and J. H. Jiang, 2013: Tropical clouds and circulation changes during the 2006/07 and 2009/10 El Niños. J. Climate, 26, 399-413, doi: 10.1175/JCLID-12-00152.1. [Link]

Su, H., J. D. Neelin, and J. E. Meyerson, 2005: Mechanisms for lagged atmospheric response to ENSO SST forcing. J. Climate, 18, 4195-4215, doi: 10.1175/JCLI3514.1. [Link]

Syndergaard, S., 2000: On the ionosphere calibration in GPS radio occultation measurements. Radio Sci., 35, 865-883, doi: 10.1029/1999RS002199. [Link]

Taguchi, M., 2010: Observed connection of the stratospheric quasi-biennial oscillation with El Niño-Southern Oscillation in radiosonde data. J. Geophys. Res., 115, D18120, doi: 10.1029/2010JD014325. [Link]

Thuburn, J. and G. C. Craig, 1997: GCM tests of theories for the height of the tropopause. J. Atmos. Sci., 54, 869-882, doi: 10.1175/1520-0469(1997)054<0869:GTOTFT>2 .0.CO;2. [Link]

Trenberth, K. E., 1984: Signal versus noise in the Southern Oscillation. Mon. Weather Rev., 112, 326-332, doi: 10. 1175/1520-0493(1984)112<0326:SVNITS>2.0.CO;2. [Link]

Trenberth, K. E., 1997: The definition of El Niño. Bull. Amer. Meteorol. Soc., 78, 2771-2777, doi: 10.1175/15 20-0477(1997)078<2771:TDOENO>2.0.CO;2. [Link]

Trenberth, K. E. and T. J. Hoar, 1996: The 1990-1995 El Niño-Southern Oscillation Event: Longest on record. Geophys. Res. Lett., 23, 57-60, doi: 10.1029/95GL03602. [Link] 
Trenberth, K. E. and L. Smith, 2006: The vertical structure of temperature in the tropics: Different flavors of El Niño. J. Climate, 19, 4956-4973, doi: 10.1175/JCLI3891.1. [Link]

Trenberth, K. E. and L. Smith, 2009: Variations in the threedimensional structure of the atmospheric circulation with different flavors of El Niño. J. Climate, 22, 29782991, doi: 10.1175/2008JCLI2691.1. [Link]

Van Loon, H. and R. L. Jenne, 1969: The half-yearly oscillations in the tropics of the southern hemisphere. J. Atmos. Sci., 26, 218-232, doi: 10.1175/1520-0469(1969)026<0218:THYOIT>2.0.CO;2. [Link]

Wallace, J. M., E. M. Rasmusson, T. P. Mitchell, V. E. Kousky, E. S. Sarachik, and H. von Storch, 1998: On the structure and evolution of ENSO-related climate variability in the tropical Pacific: Lessons from TOGA. J. Geophys. Res., 103, 14241-14259, doi: 10.1029/97JC02905. [Link]

Webster, P. J., 1983: The large-scale structure of the tropical atmosphere. In: Hoskins, B. J. and R. P. Pearce (Eds.), Large Scale Dynamical Processes in the Atmosphere, Academic Press, London, 235-275.

Webster, P. J. and H. R. Chang, 1988: Equatorial energy accumulation and emanation regions: Impacts of a zon- ally varying basic state. J. Atmos. Sci., 45, 803-829, doi: 10.1175/1520-0469(1988)045<0803:EEAAER >2 .0.CO;2. [L Link]

Webster, P. J., V. O. Magaña, T. N. Palmer, J. Shukla, R. A. Tomas, M. Yanai, and T. Yasunari, 1998: Monsoons: Processes, predictability, and the prospects for prediction. J. Geophys. Res., 103, 14451-14510, doi: 10.1029/97JC02719. [Link]

World Meteorological Organization (WMO), 1957: Definition of the tropopause. World Meteorol. Organ. Bull., $6,136$.

$\mathrm{Xu}, \mathrm{X}$. and J. Luo, 2008: Validation of COSMIC RO profiles with radiosonde soundings. Proc. SPIE, 7285, doi: 10.1117/12.816351. [Link]

Yulaeva, E. and J. M. Wallace, 1994: The signature of ENSO in global temperature and precipitation fields derived from the microwave sounding unit. J. Climate, 7, 17191736, doi: 10.1175/1520-0442(1994)007<1719:TSOEI $\mathrm{G}>2.0 . \mathrm{CO} ; 2$. [Link $]$

Zhou, X., M. A. Geller, and M. Zhang, 2001: Tropical cold point tropopause characteristics derived from ECMWF reanalyses and soundings. J. Climate, 14, 1823-1838, doi: 10.1175/1520-0442(2001)014<1823:TCPTCD>2. $0 . \mathrm{CO} ; 2$. [Link] 